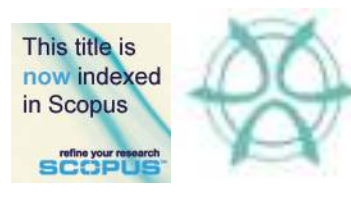

PLANNING MALAYSIA:

Journal of the Malaysian Institute of Planners

SPECIAL ISSUE IV (2016), Page 395 - 410

\title{
AN INVESTIGATION ON THE RELATIONSHIP BETWEEN LAND USE COMPOSITION AND PM10 POLLUTION IN ISKANDAR MALAYSIA
}

\author{
Muhammad Azahar Zikri Zahari'1, M. Rafee Majid², Ho Chin Siong ${ }^{3}$, Gakuji \\ Kurata $^{4} \&$ Nadhirah Nordin 5 \\ 1,2,3,5 UNIVERSITI TEKNOLOGI MALAYSIA \\ ${ }^{4}$ KYOTO UNIVERSITY, JAPAN
}

\begin{abstract}
This paper discusses the relationship between land use composition and the degree of air pollution, specifically $\mathrm{PM}_{10}$, in Iskandar Malaysia. Aspiring to be a low carbon region and a smart city, Iskandar Malaysia has to meet the social and economic needs of its growing population while taking care of all the environmental challenges that come with rapid urbanization. The intermittent regional haze episodes in the past years have shrouded this region with particulate matters including $\mathrm{PM}_{10}$, but the major cause of the haze was extensive agricultural open burning rather than land use change. Since there is no doubt land use change itself can be a significant contributor to local $\mathrm{PM}_{10}$ concentration, separating $\mathrm{PM}_{10}$ caused by the local (land use change) source from that of the regional source would enable us to investigate the trend in local PM10 pollution level.

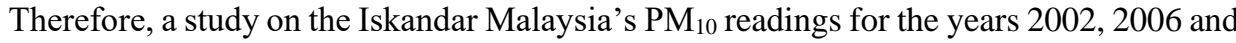
2008 was carried out with the aim to identify the relationship between land use composition and $\mathrm{PM}_{10}$ concentrations. The background concentration of $\mathrm{PM}_{10}$ was extracted by using the base flow separation process commonly used in the hydrograph study. The extracted background concentration was then interpolated with the Terra MODIS level 2 product to identify the $\mathrm{PM}_{10}$ concentration for the whole Iskandar Malaysia region, spatially. Since data for land use changes are compositional data in nature, where the percentages of different land use coverages always add up to unity, the barycentric or ternary plot had been used to investigate the relationship between $\mathrm{PM}_{10}$ concentrations with the land use composition (urban:agriculture:forest) in Iskandar Malaysia. The results show that air quality as represented by $\mathrm{PM}_{10}$ concentrations are inevitably linked to the land use changes at the local level notwithstanding the more noticeable but intermittent influence of the regional haze episodes. The degree of air pollution is noticeably controlled by the percentage of urban land use with $\mathrm{PM}_{10}$ clearly affected by the size of commercial area.
\end{abstract}

Keyword: $\mathrm{PM}_{10}$; land use composition; remote sensing; Iskandar Malaysia 
Muhammad Azahar Zikri Zahari, M. Rafee Majid, Ho Chin Siong, Gakuji Kurata \& Nadhirah Nordin An Investigation on the Relationship between Land Use Composition and PM $M_{10}$ Pollution in Iskandar Malaysia

\section{INTRODUCTION}

Particulate matter is often condemned as an agent that negatively affects local climate and health. Ramanathan and Carmichael (2008) stated that black carbon warmed the climate in two ways. The particulates warm the air by absorbing sunlight and generate heat in the atmosphere when suspended in the air.This affects regional cloud formation and precipitation patterns. The climate effects of this warming agent were found to be strongly regional because black carbon remained in the atmosphere for only one to four weeks.

Iskandar Malaysia had faced air pollution from both regional source and local emissions. Transboundary pollution faced by this region is the haze episodes that intermittently shroud Southeast Asia since 1972. Focusing on local emission, this study considered the regional sources of air pollution as noise. Separating locally emitted $\mathrm{PM}_{10}$ from the transboundary pollution would enable us to clarify the relationship between local particulate matter emission and land use changes. Geo-information is a good platform to study particulate matter through its spatial perspective. The presence of particulate matters best indicated using PM1, PM2.5, PM4 and PM PM $_{10}$ concentrations. Since this study focuses on $\mathrm{PM}_{10}$, Aerosol Optical Depth product of Moderate Resolution Imaging Spectroradiometer (MODIS AOD) were used to verify the local particulate matter pattern, while land use changes were detected using satellite images, Landsat Thematic Mapper (from year 1984 to 2008). Based on the monitoring data and ambient air quality studies, several large cities in Malaysia are facing high level of air pollutants that are not always at acceptable levels (DOE, 2002). Following this, the Department of Environment (DOE) Malaysia adopted the current Air Pollutant Index (API) standards in order to revise their old index system in 1996. The basis for the interpretation of the API had been explained in the Malaysian Ambient Air Quality Guidelines (Table 1: The "safe levels" for the listed concentration pollutant). Highlighted in this study, the average threshold limit for $\mathrm{PM}_{10}$ are $150 \mu \mathrm{g} / \mathrm{m} 3$ and $50 \mu \mathrm{g} / \mathrm{m} 3$ for 24 -hour and 1-year averaging time respectively.

Table 1: Malaysian ambient air quality guidelines

\begin{tabular}{|c|c|c|c|}
\hline \multirow{2}{*}{ Pollutant } & \multirow{2}{*}{ Averaging Time } & \multicolumn{2}{|c|}{ Malaysia Guideline } \\
\cline { 3 - 4 } & & $\mathbf{p p m}$ & $\boldsymbol{\mu g} / \mathbf{m}^{\mathbf{3}}$ \\
\hline \multirow{2}{*}{ Particulate Matter $\left(\mathrm{PM}_{10}\right)$} & $24 \mathrm{~h}$ & - & 150 \\
& 1 year & - & 50 \\
\hline \multirow{2}{*}{ Carbon Monoxide $(\mathrm{CO})$} & $1 \mathrm{~h}$ & 30 & 35 \\
& $8 \mathrm{~h}$ & 9 & - \\
\hline \multirow{2}{*}{ Nitrogen Dioxide $\left(\mathrm{NO}_{2}\right)$} & $1 \mathrm{~h}$ & 0.17 & 320 \\
& $24 \mathrm{~h}$ & 0.04 & 10 \\
\hline \multirow{2}{*}{ SulphurDioxide $\left(\mathrm{SO}_{2}\right)$} & $1 \mathrm{~h}$ & 0.13 & 350 \\
& $24 \mathrm{~h}$ & 0.04 & 105 \\
\hline \multirow{2}{*}{ Ozone $\left(\mathrm{O}_{3}\right)$} & $1 \mathrm{~h}$ & 0.1 & 200 \\
& $8 \mathrm{~h}$ & 0.06 & 120 \\
\hline
\end{tabular}

Source: Department of Environment, Malaysia (2002)

\section{Transboundary Pollution vs. Local Emissions}

There have been many discussions among researchers on the sources of air pollution. At this juncture, it is important to differentiate between transboundary pollution and local emissions. According to Nguyen (2010), air pollution sources included both local emissions and long-range transported pollution (or transboundary pollution). 
Transboundary pollution was defined as atmospheric pollutants transported over huge distances, which caused negative impacts on the environment of receptor sites. Local emission sources can be minimised or controlled, whereas transboundary pollution affected and challenged regional policies and regulations. The possible types and factors of transboundary pollution were listed in Table 2 . Transboundary pollution could also be triggered by a dust storm, wildfires, agriculture burning or even anthropogenic emissions.

Table 2: Type and events of transboundary pollution.

\begin{tabular}{|c|c|c|c|}
\hline Pollution source & Receptor site & Source site & Reference \\
\hline \multicolumn{4}{|l|}{ Dust storm } \\
\hline $\begin{array}{l}\text { Dust } \\
\text { storm }\end{array}$ & Taiwan & $\begin{array}{l}\text { Inner Mongolia in } \\
\text { northern China }\end{array}$ & $\begin{array}{l}\text { Liu et al., } \\
2009\end{array}$ \\
\hline $\begin{array}{l}\text { Dust } \\
\text { storm }\end{array}$ & Beijing, China & $\begin{array}{l}\text { Desert regions of Mongolian and } \\
\text { northern China }\end{array}$ & Zhang et al., 2009 \\
\hline Dust days & Beijing & - & Wang et al., 2006 \\
\hline $\begin{array}{l}\text { Dust } \\
\text { storm }\end{array}$ & French Alps & Sahara desert & Aymoz et al., 2004 \\
\hline \multicolumn{4}{|c|}{ Anthropogenic pollution } \\
\hline $\begin{array}{l}\text { Anthropogenic } \\
\text { pollution }\end{array}$ & Taiwan & $\begin{array}{l}\text { Mainland } \\
\text { China }\end{array}$ & $\begin{array}{l}\text { Junker } \text { et } \\
\text { al., } 2009\end{array}$ \\
\hline $\begin{array}{l}\text { Anthropogenic } \\
\text { pollution }\end{array}$ & Taiwan & $\begin{array}{l}\text { Mainland } \\
\text { China }\end{array}$ & $\begin{array}{l}\text { Lin et al., } \\
2005\end{array}$ \\
\hline $\begin{array}{l}\text { Anthropogenic } \\
\text { pollution }\end{array}$ & Jeju island, Korea & China & Nguyen et al., 2009 \\
\hline \multicolumn{4}{|l|}{ Biomass burning } \\
\hline $\begin{array}{l}\text { Wildfire; } \\
\text { agriculture burning }\end{array}$ & $\begin{array}{l}\text { Helsinki, } \\
\text { Finland }\end{array}$ & $\begin{array}{l}\text { Eastern Europe } \\
\text { (Russia, Belarus, Ukraine) }\end{array}$ & $\begin{array}{l}\text { Niemi } \text { et al., } \\
2009\end{array}$ \\
\hline $\begin{array}{l}\text { Biomass } \\
\text { burning }\end{array}$ & UK & Russia & $\begin{array}{l}\text { Witham and } \\
\text { Manning, } 2007\end{array}$ \\
\hline $\begin{array}{l}\text { Biomass } \\
\text { burning }\end{array}$ & Aveiro, Portugal & $\begin{array}{l}\text { Different inland regions of Iberian } \\
\text { Peninsula }\end{array}$ & Pio et al., 2008 \\
\hline Forest fire burning & $\begin{array}{l}\text { Missoula, Montana, } \\
\text { USA }\end{array}$ & Western Montana, USA & Ward et al., 2006 \\
\hline Biomass burning & Washington, USA & $\sim 200 \mathrm{~km}$ on eastern & $\begin{array}{l}\text { Jimenez et al., } \\
2006\end{array}$ \\
\hline Forest fires & Rondonia, Brazil & $\begin{array}{l}\text { Washington State } \\
\text { Rondinia }\end{array}$ & $\begin{array}{l}\text { Graham et al., } \\
2002\end{array}$ \\
\hline Biomass burning & Seoul, Korea & Korea and China & Kang et al., 2004 \\
\hline Biomass burning & $\begin{array}{l}\text { Kuala Lumpur, } \\
\text { Malaysia }\end{array}$ & Indonesia & Fang et al., 1999 \\
\hline Biomass burning & $\begin{array}{l}\text { Kuala Lumpur, } \\
\text { Malaysia }\end{array}$ & $\begin{array}{l}\text { Southern Sumatra and Kalimantan, } \\
\text { Indonesia }\end{array}$ & Abas et al., 2004 \\
\hline Biomass burning & Singapore & Indonesia & See et al., 2006 \\
\hline Biomass burning & Brunei Darussalam & Indonesia & $\begin{array}{l}\text { Radojevic and } \\
\text { Hassan, } 1999\end{array}$ \\
\hline
\end{tabular}

Haze that shrouds Southeast Asian annually is often being condemned as the main factor of degrading air quality in this region. As the criticism continues, we have forgotten that local emission is also one of the contributors on this matter. Particulate matters emitted by urban activities area constant source of pollution, while haze episodes are intermittent. Coal burning was the principal source of particulate matter emissions and air pollution emissions. Haq and Schwela (2008) stated that in most urban areas in Asia, 
Muhammad Azahar Zikri Zahari, M. Rafee Majid, Ho Chin Siong, Gakuji Kurata \& Nadhirah Nordin An Investigation on the Relationship between Land Use Composition and PM ${ }_{10}$ Pollution in Iskandar Malaysia

the most important sources of air pollution were from motor vehicles, particularly those fuelled by diesel fuel and two stroke engines. The largest motorcycle fleet in the world was found in the Asian region since motorcycles were the cheapest mode of individual motorised transportation for the expanding working class in Asia. The backyard burning of refuse (garbage and biomass) still created noticeable and perhaps considerable air pollution. Street cooking was another source of concern, which was important in many urban areas. Therefore, the stated reviews proved that the blame of air pollution and particulate matter emission was not on the intermittent haze episode alone.

Local emission from Iskandar Malaysia may be related to its land use composition trend, which indicates heavily industrialised urban area with higher private vehicles dependency. Therefore, this research was formulated to identify the relationship between land use composition and air quality $\left(\mathrm{PM}_{10}\right)$. This may help Iskandar Malaysia to control local emission through a proper land use management. As the study focused on rapid urban growth in Iskandar Malaysia, the important air pollutant parameters considered is $\mathrm{PM}_{10} . \mathrm{PM}_{10}$ was mainly emitted by industrial and transportation activities, which were considered as main urban activities.

In addition to local emissions, urban air quality may also be affected by global, regional or transboundary pollutants. However, the scenario of air pollution in Malaysia's urban area is likely triggered more by local emissions since transboundary pollution occurred intermittently. Results of an analysis by Ling et al. (2010) showed that the number of unhealthy days had a significant and strong relationship with urban land uses in Kuala Lumpur. The finding was contrary to the local party's argument, which strictly blamed the high concentration of air pollutants in the Malaysian capital on forest fires in a neighbouring country (haze). The findings showed that local emissions of $\mathrm{PM}_{10}$, through urban activities, played a big role in the degradation of air quality in Malaysia.

Emissions from mobile sources were a major source of air pollution, which contributes to at least 70 to 75 percent of total air pollution. Behind mobile sources, emissions from stationary sources generally contribute 20 to 25 percent, while open burning and forest fires contribute approximately 3 to 5 percent. A study by the Department of Environment Malaysia (1996), showed that motor vehicles contributed 82 percent of emission towards air pollution. Other sources contributing to air pollution were power stations ( 9 percent), followed by industrial fuel burning ( 5 percent), industrial production processes ( 3 percent), domestic and commercial furnaces $(0.2$ percent $)$ and open burning at solid-waste disposal sites ( 0.8 percent).

Therefore, the blame of degradation of air quality in Malaysia should not be put on transboundary pollution alone. Local emission contribution to the degrading air quality should be taken seriously, since these emissions are not intermittent but continual. In addition, while transboundary pollution is not to be dealt with at a local level, local authorities in Malaysia could control local emissions. Therefore, local policies should seriously focus on lowering local emissions by promoting a low carbon lifestyle, green industries and other appropriate measures.

\section{METHOD}

Two main variables of this study are air pollution as represented by $\mathrm{PM}_{10}$ concentrations and land use changes. As shown in Figure 1, these variables had been through several 
processes in order to clarify the relationship between air pollution and land use composition in Iskandar Malaysia.

The air pollution involves two types of data which are in situ data; retrieved from Department of Environment, Malaysia (DOE), and spatial data; MODIS Aerosol Optical Depth data. Due to the limited number of monitoring stations, DOE's in situ readings were used to interpolate with MODIS Aerosol Optical Depth value. This process is important to comprehensively estimate concentrations for the whole Iskandar Malaysia, spatially. On other side, clarification of land use changes involves two types of data which are land use database; accessed from the Iskandar Region Development Authority, and LANDSAT Thematic Mapper satellite images; retrieved from the United States Geological Survey. Land uses had been extracted from those satellite images through supervised classification technique. The land use changes had been investigated by calculating the percentage of accretion changes using the change detection technique. Those processed data; air pollution and land use data, were used in the analysis process. The ternary plot technique was used to identify the relationship between land use composition and air pollution level. Through those processes and analysis, the relationship between those variables explains the local air pollution scenario in Iskandar Malaysia.

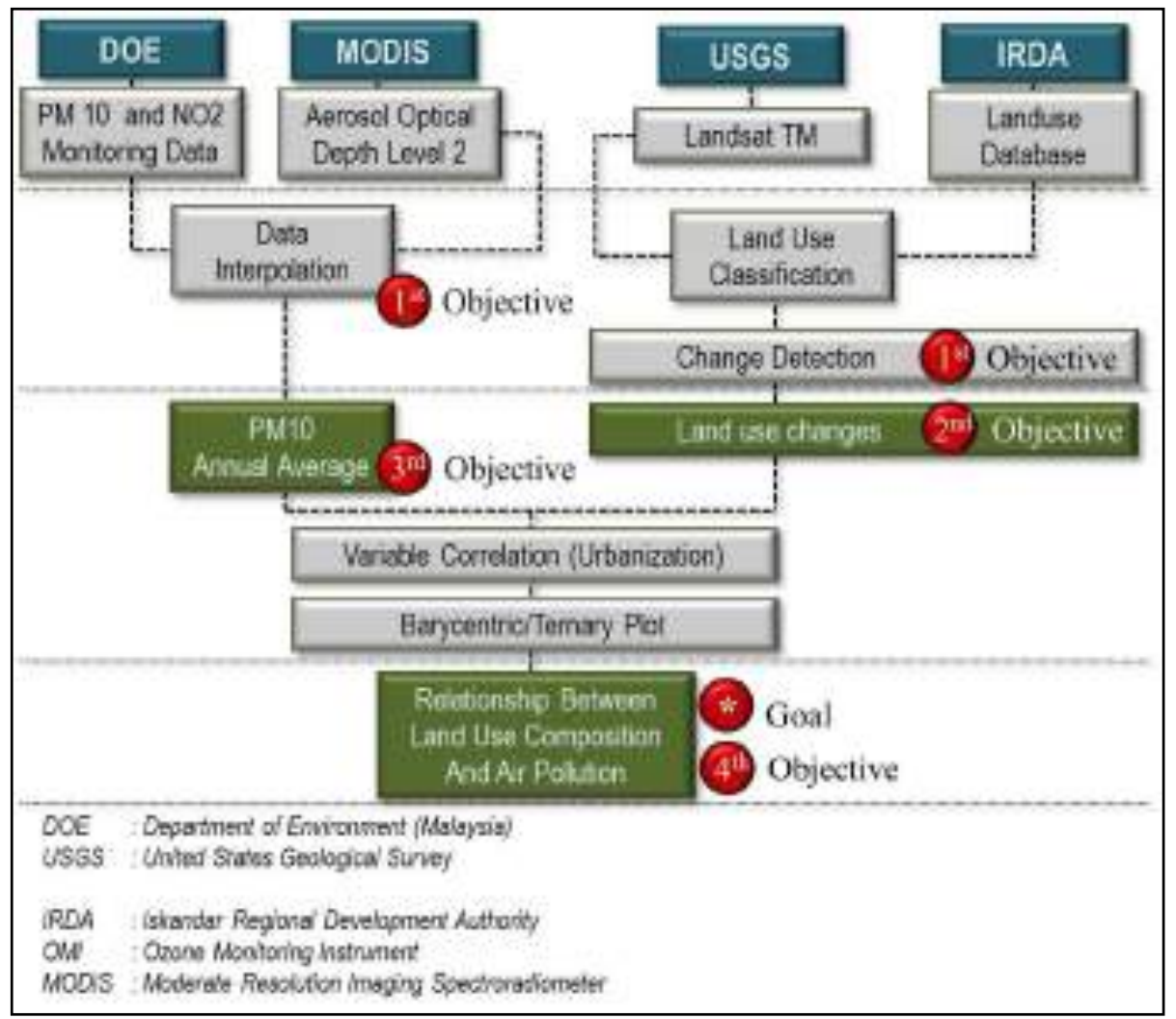

Figure 1: Method adopted in this study 
Muhammad Azahar Zikri Zahari, M. Rafee Majid, Ho Chin Siong, Gakuji Kurata \& Nadhirah Nordin

An Investigation on the Relationship between Land Use Composition and PM $M_{10}$ Pollution in Iskandar Malaysia

\section{PROCESSED DATA}

As mentioned above, there were several data that had been processed which included in situ data; DOE's monitoring stations data $\left(\mathrm{PM}_{10}\right)$, satellite images; LANDSAT Thematic Mapper (1984-2008), and aerosol spatial data; MODIS Aerosol Optical Depth (20022008). Those data were required to show the significance of the relationship between particulate matter and land use changes.

\section{MODIS Aerosol Optical Depth (2002-2008)}

For the past several years, the air quality monitoring stations had been monitoring particulate matter concentrations but lacked spatial information since there were only three stations. Due to this limitation, MODIS Aerosol Optical Depth data were used to interpolate and comprehensively estimate the missing values spatially. Iskandar Malaysia boundary falls within only ten out of sixteen grids of the aerosol optical depth(grid dimension: 0.2 degrees by 0.2 degrees). As shown in Figure 2, Terra Atmosphere Level 2 product data were used for this process. The separation between transboundary haze and local emissions were performed for the MODIS AOD data. Therefore, the transboundary pollution data during haze episodes were removed. The annual averages of $\mathrm{PM}_{10}$ concentrations were then cross-selected with land use data. This process was done to accurately analyse the relationship. The selected annual average readings are for the years of 2002, 2006 and 2008. There were about thirty grids of annual average data available that could be analysed with the land use distribution data. In this study, the $\mathrm{PM}_{10}$ readings were very important. However, the data derived from the MODIS AOD grid value was not particulate matter concentration. Therefore, a correlation between those monitoring data is also very essential to predict the $\mathrm{PM}_{10}$ readings for other uncovered areas. A close relationship had been identified between the MODIS AOD grid value and the monitored $\mathrm{PM}_{10}$ concentrations using mix effects model (Table 3).

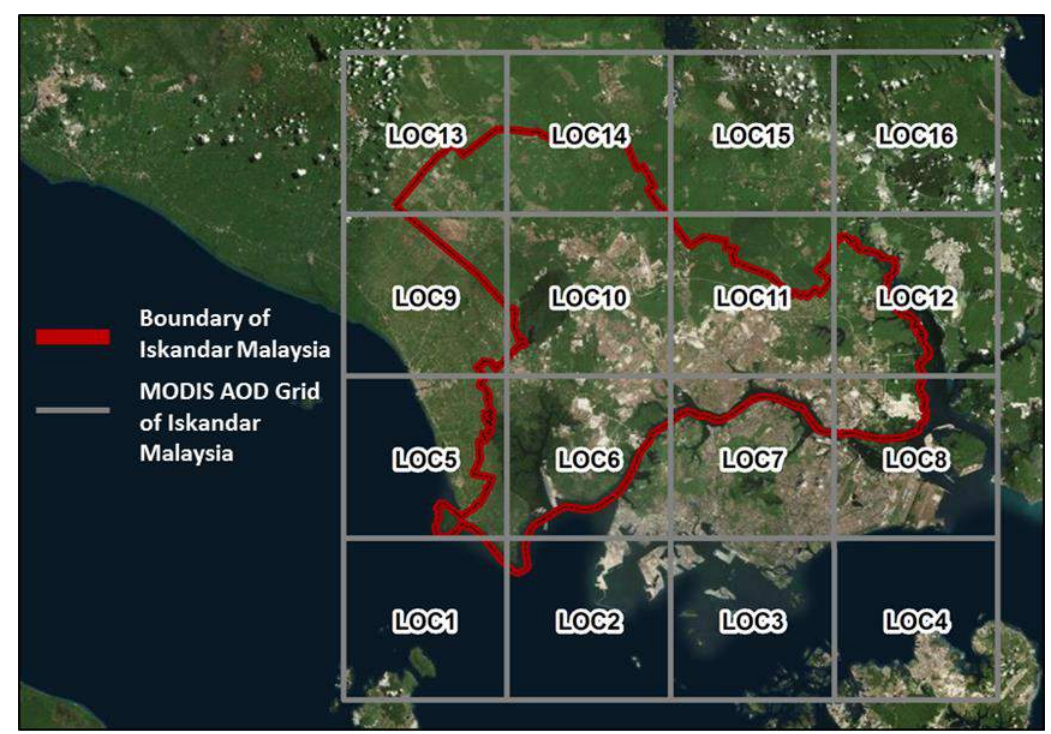

Figure 2: MODIS AOD grid of Iskandar Malaysia 
Table 3: Calculated $\mathrm{PM}_{10}$ value, predicted using MODIS AOD grid values

\begin{tabular}{|c|c|c|c|c|}
\hline \multirow[t]{2}{*}{ YEARS } & \multicolumn{2}{|r|}{ LOCATION } & \multirow{2}{*}{$\begin{array}{c}\begin{array}{c}\text { MODIS AOD Grid } \\
\text { Value(annual average) }\end{array} \\
265.852116\end{array}$} & \multirow{2}{*}{$\begin{array}{c}\begin{array}{c}\text { Predicted } \mathrm{PM}_{10} \\
\text { Value(annual average) }\end{array} \\
31.25915667\end{array}$} \\
\hline & LOC5 & Pulau Kukup & & \\
\hline \multirow{9}{*}{ 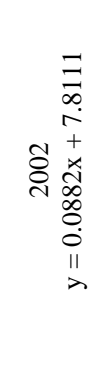 } & LOC6 & $\begin{array}{c}\text { Gelang Patah \& } \\
\text { Nusajaya }\end{array}$ & 291.023543 & 33.47927655 \\
\hline & LOC7 & Johor Bahru \& Permas & 375.798186 & 40.95640002 \\
\hline & LOC8 & Pasir Gudang & 306.735493 & 34.86507056 \\
\hline & LOC9 & Tmn Putri, Kulai & 264.577092 & 31.14669954 \\
\hline & LOC 10 & Skudai \& Senai & 284.554563 & 32.9087125 \\
\hline & LOC11 & Ulu Tiram & 287.461924 & 33.16514177 \\
\hline & LOC12 & $\begin{array}{c}\text { Kg Delima, Pasir } \\
\text { Gudang }\end{array}$ & 280.480070 & 32.54934222 \\
\hline & LOC 13 & Kg Sri Paya, Kulai & 267.763567 & 31.42774664 \\
\hline & LOC14 & Sedenak & 278.375440 & 32.36371389 \\
\hline \multirow{10}{*}{ 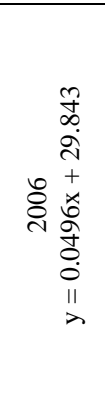 } & LOC5 & Pulau Kukup & 227.989497 & 41.15127903 \\
\hline & LOC6 & $\begin{array}{c}\text { Gelang Patah \& } \\
\text { Nusajaya }\end{array}$ & 268.232292 & 43.14732166 \\
\hline & LOC7 & Johor Bahru \& Permas & 286.768519 & 44.06671852 \\
\hline & LOC8 & Pasir Gudang & 293.092130 & 44.38036962 \\
\hline & LOC9 & Tmn Putri, Kulai & 251.578150 & 42.32127623 \\
\hline & LOC 10 & Skudai \& Senai & 237.942550 & 41.64495046 \\
\hline & LOC 11 & Ulu Tiram & 254.157788 & 42.44922628 \\
\hline & LOC12 & $\begin{array}{l}\text { Kg Delima, Pasir } \\
\text { Gudang }\end{array}$ & 247.558929 & 42.12192285 \\
\hline & LOC13 & Kg Sri Paya, Kulai & 253.300562 & 42.40670789 \\
\hline & LOC14 & Sedenak & 251.142598 & 42.29967287 \\
\hline \multirow{10}{*}{ 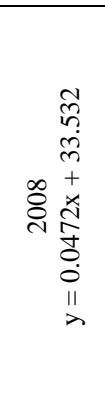 } & LOC5 & Pulau Kukup & 296.384091 & 47.52132909 \\
\hline & LOC6 & $\begin{array}{c}\text { Gelang Patah \& } \\
\text { Nusajaya }\end{array}$ & 407.743827 & 52.77750864 \\
\hline & LOC7 & Johor Bahru \& Permas & 425.944444 & 53.63657778 \\
\hline & LOC8 & Pasir Gudang & 343.856790 & 49.7620405 \\
\hline & LOC9 & Tmn Putri, Kulai & 293.486688 & 47.38457169 \\
\hline & LOC 10 & Skudai \& Senai & 351.439394 & 50.11993939 \\
\hline & LOC11 & Ulu Tiram & 399.612500 & 52.39371 \\
\hline & LOC12 & $\begin{array}{c}\text { Kg Delima, Pasir } \\
\text { Gudang }\end{array}$ & 352.167154 & 50.15428967 \\
\hline & LOC13 & Kg Sri Paya, Kulai & 254.961689 & 45.56619176 \\
\hline & LOC14 & Sedenak & 304.413874 & 47.90033487 \\
\hline
\end{tabular}

\section{LANDSAT Thematic Mapper (1984-2008)}

Monitoring land use changes in Iskandar Malaysia from the previous year was important in order to understand the impact of land use changes towards the anthropogenic impact during those periods. In order to analyse the changes, this research required several sets of satellite images to indicate the land cover of the selected years. The satellite images used in this research were obtained from LANDSAT Thematic Mapper (TM). The Landsat programme had introduced Thematic Mapper (TM) as an Earth observing sensor. This observing sensor was initially placed aboard Landsat 4 (decommissioned in 2001), then it had continued the operation aboard Landsat 5 for the recent years up to 2012. There were seven bands of image data featured in TM sensors, which had 30-metre spatial resolution (four in infrared and the other three in visible wavelengths). TM did not directly produce a thematic map, because it was functionally similar as the whisk broom scanner, 
Muhammad Azahar Zikri Zahari, M. Rafee Majid, Ho Chin Siong, Gakuji Kurata \& Nadhirah Nordin An Investigation on the Relationship between Land Use Composition and PM $M_{10}$ Pollution in Iskandar Malaysia

which took multi-spectral images across its ground track. Recently, Landsat 7 was used for the recent year's images and it was aboard with the Enhanced Thematic Mapper Plus $(\mathrm{ETM}+)$.

In order to measure the spread urbanisation in Iskandar Malaysia, LANDSAT TM satellite images were used to differentiate the built-up area from non-built-up area. This classification derived the increased built-up area as caused by urbanisation. Figure 3 shows the urbanisation progress of Iskandar Malaysia (1984 to 2008), which were processed from LANDSAT TM satellite images using supervised classification in ENVI software. According to the figure, the built-up area of Iskandar Malaysia had rapidly increased during 1990 to 1997 , which evidently proved that Malaysia urbanised rapidly during the 90's, when government focused on the industrial sector; increase 5712.13 acres per year. The areas of built-up areas in Iskandar Malaysia started at 29,486.33 acres in 1984, and continuously increased to include a total area of 110,050.86 acres in2008 The process itself provided many great opportunities in the economic sector, but was still a major contributor towards air pollution.
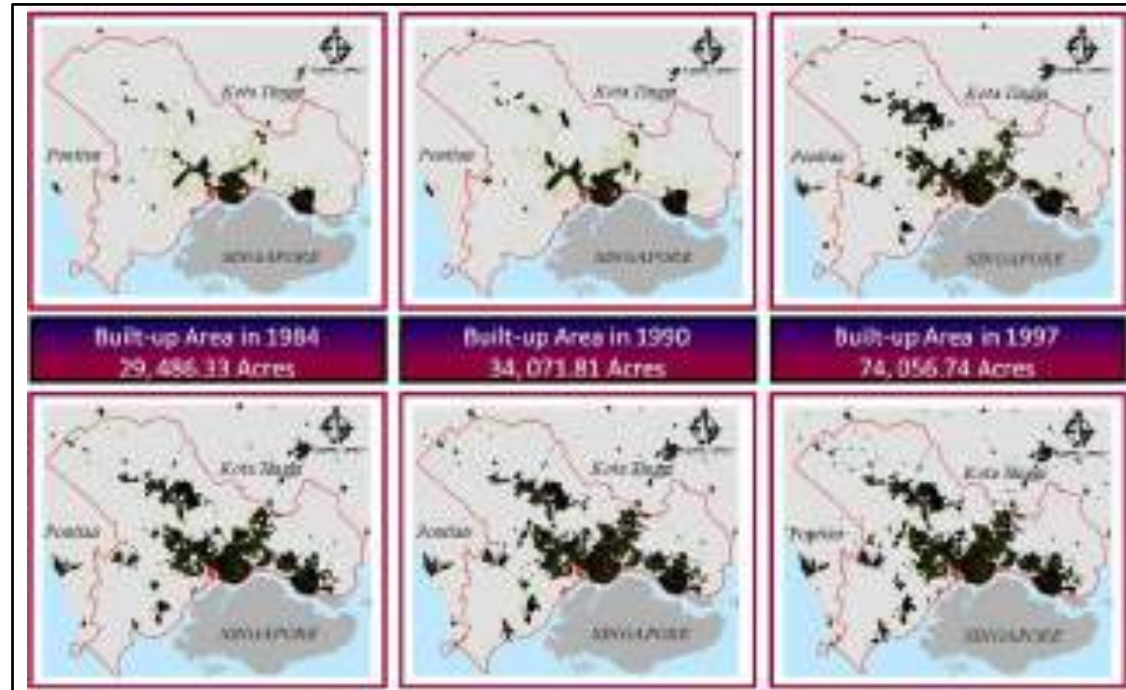

Buitr lop Area in 2002

91.377 .35 Aares

Buitr-up Area in 2006

$102,912.52$ Aares
Buthe Ares in 2005

110, 05086 Acres

Figure 3: Urban expansion of Iskandar Malaysia, 1984-2008

According to the extracted urban land use of Iskandar Malaysia, the increasing acreage of built-up area had been of significance to particulate matter emissions. Therefore, a more detailed analysis of the built-up area was performed to analyse the effect of built-up area towards particulate matter emission. A cross-tabulation between built up area and the land use database was done to measure the land use changes periodically. Figure 4 shows land use change map of Iskandar Malaysia from the year of 1984 to 2008. According to the measured rates of land use change, the highest rate of change was observed between the year of 1990 and 1997; built-up area increase 5,712.13 acres per year. As a concern in this research, the land use changes were not an indicator 
to prove that Malaysia was growing economically, but as an indicator of land use influence towards the degradation of air quality in Iskandar Malaysia.

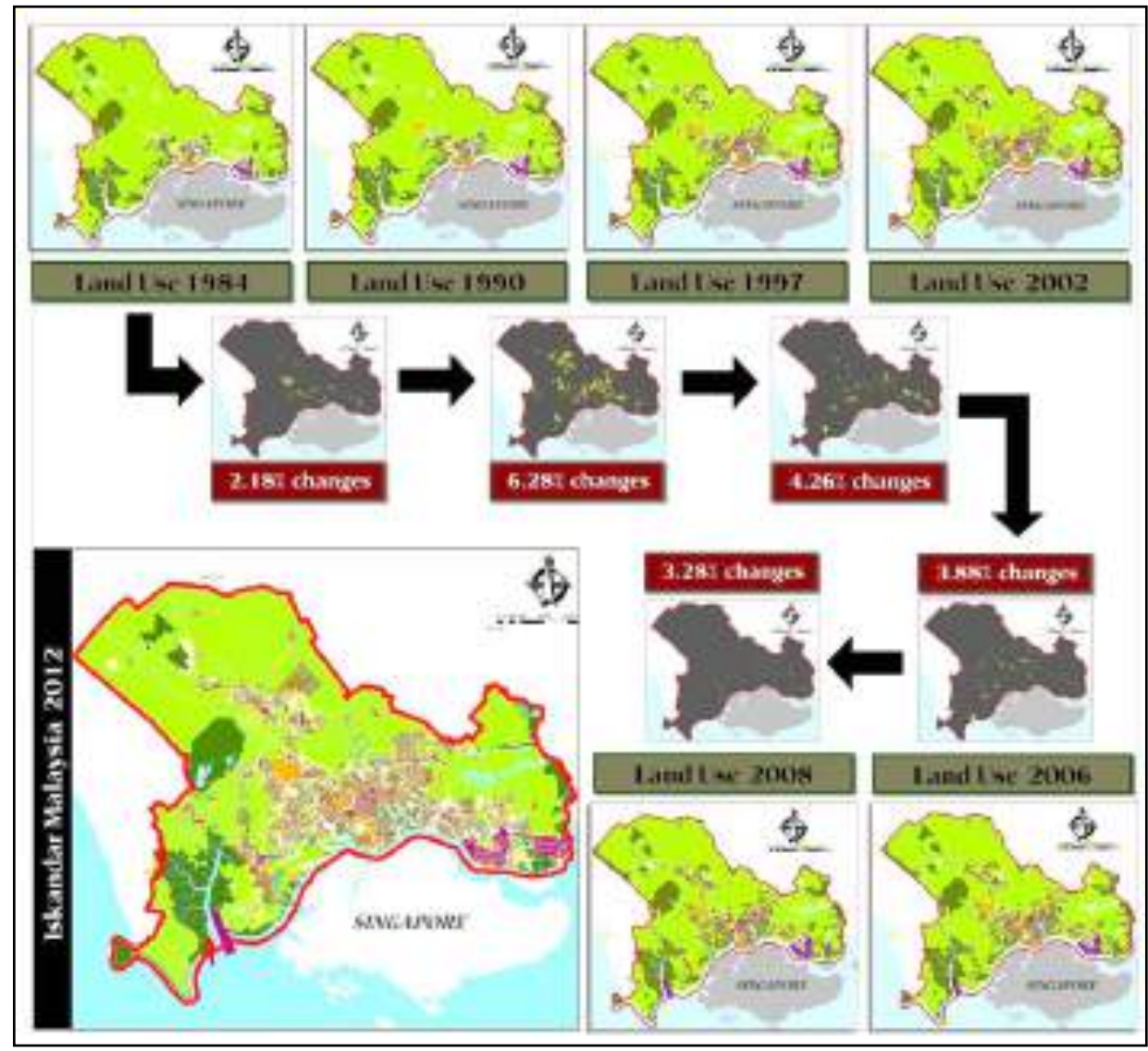

Figure 4: Map of land use changes in Iskandar Malaysia, 1984-2008

Extracted from the land use change map, the acreage of changes in Iskandar Malaysia was plotted in agraph (Figure 5). The processed data indicates that the major land use change was the change from agricultural activities to residential and industrial activities, with total acreage changes of 4937.17 acres/year and 1562.122 acres/year, respectively, for the whole period. Even though the highest change was from agricultural to residential, but still, the second highest changes were industrial activities. In addition, the figure showed that there were very low practices of brown field and infill development in Iskandar Malaysia, since the major change happened from agricultural and forest. 
Muhammad Azahar Zikri Zahari, M. Rafee Majid, Ho Chin Siong, Gakuji Kurata \& Nadhirah Nordin An Investigation on the Relationship between Land Use Composition and PM ${ }_{10}$ Pollution in Iskandar Malaysia

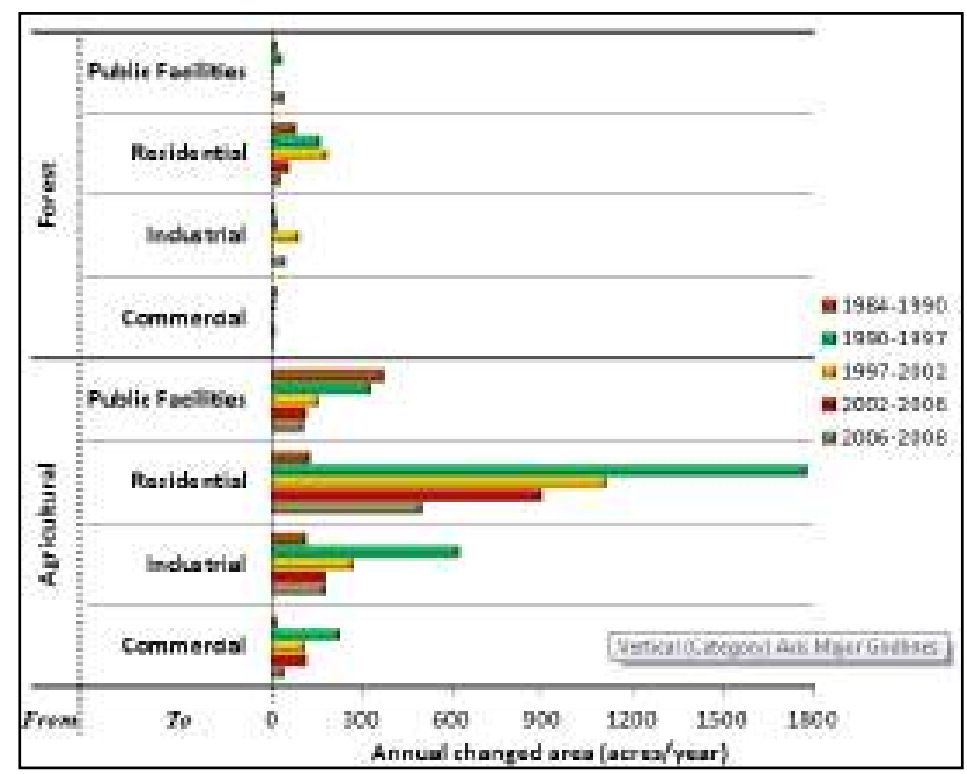

Figure 5: Land use changes process in Iskandar Malaysia, 1984-2008

\begin{abstract}
ANALYSIS AND FINDINGS
A ternary or barycentric plot is a compositional graph that involves three axes bounded to each other which sum to a unity (Figure 6). It graphically illustrates the ratios of the three axes as positions in a triangle. Compositional data is usually plotted on this type of graph. This method is commonly used in physical mineralogy, petrology, metallurgy, chemistry and other physical sciences to show the compositions of systems consisting of three elements. In this research, the usage of this plot to study the relationship between land use composition and air pollutants seemed to be applicable. Fortunately, adding another perpendicular axis to this plot enabled us to identify the relationship between those compositional data with that perpendicular axis value. The derived perpendicular axis was adapted in this research to show the air pollutant concentrations, called a contour ternary plot. In order to determine the relationship surface, a kriging technique was used to interpolate the sample values.

Trying to read a ternary plot can be confusing because there are three axes bound to each other in order to plot compositional data. As shown in Figure 5.4, a ternary plot contains three main axes used to plot three types of elements in one composition. To use an example plotted by the red dot, this composition contained a ratio of $0.375: 0.375: 0.250$ of elements A, B and C. Therefore, by understanding Figure 6, it is not very difficult to understand a ternary plot.
\end{abstract}




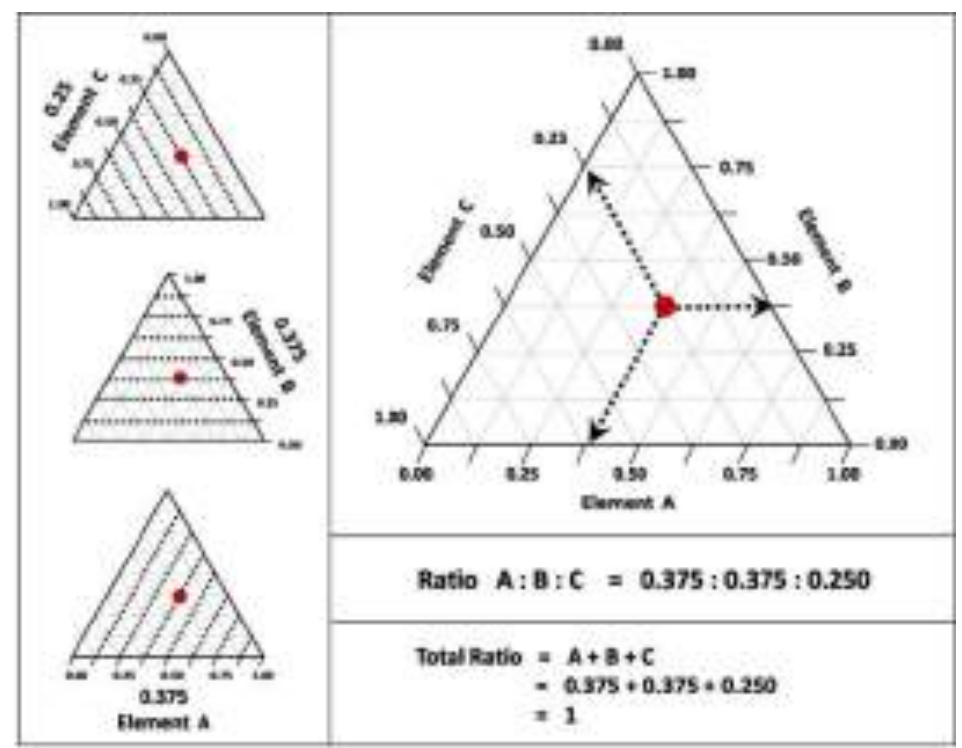

Figure 6: How to read a barycentric or ternary plot

\section{Impact of Urban: Agriculture: Forest Land Use Composition onPM10}

Every land use composition involved in this research was plotted against the air pollutants. As the axes are limited to only three, several mix compositions had been considered to indicate the different land use scenarios. Figure 7 shows the pattern of $\mathrm{PM}_{10}$ for the composition ofurban: agriculture: forest. The urban proportion made up the majority of urban land use in Iskandar Malaysia; consisting of industrial, residential, commercial and public facilities. It was found that these air pollutants had a different pattern. As shown in the figure, the main cause of increasing $\mathrm{PM}_{10}$ pollution was 'urban'. As the urban proportion increased, the annual average of $\mathrm{PM}_{10}$ concentration tended to increase. In general, this fact proved that urban activities were the main factor of $\mathrm{PM}_{10}$ local emissions in Iskandar Malaysia. 
Muhammad Azahar Zikri Zahari, M. Rafee Majid, Ho Chin Siong, Gakuji Kurata \& Nadhirah Nordin An Investigation on the Relationship between Land Use Composition and PM $M_{10}$ Pollution in Iskandar Malaysia

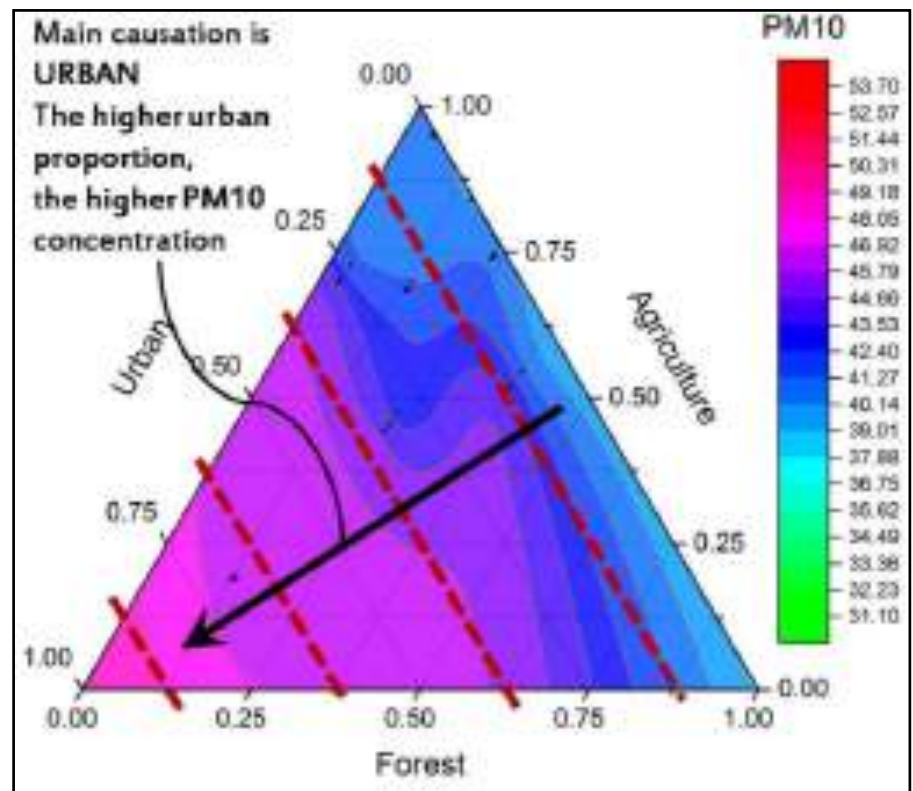

Figure 7: $\mathrm{PM}_{10}$ pattern for urban: agriculture: forest land use composition in Iskandar Malaysia

\section{Impact of Industry: Commercial: Residential Land Use Composition on $\mathbf{P M}_{10}$}

A more detailed analysis had been done to identify the land uses in urban area that contributed highly to the degrading of air quality. As shown in Figure 8, the pattern of $\mathrm{PM}_{10}$ for the composition of the land use in Iskandar Malaysia's urban area clearly illustrated that the commercial sector was the main cause of the $\mathrm{PM}_{10}$ annual average concentrations. As a matter of fact, if the commercial proportion increased, the $\mathrm{PM}_{10}$ annual average concentration increased along. This was not as expected, because industrial activities are usually blamed as the main source of air pollutants. The collected data proved that the emissions from commercial activities were the main contributor to air pollution, followed by industrial activities. Upon closer observation, this scenario happens because the major contributor for $\mathrm{PM}_{10}$ was transportation activities in commercial areas. Commercial areas in Iskandar Malaysia were smaller in size, but higher in transportation activities. The community in Iskandar Malaysia preferred to use private vehicles rather than walking or other green modes of transportation. This was supported by the fact that commercial areas usually attracted a large number of people, in addition to transportation activities that were not environment-friendly.

Yet another composition of urban: forest: agriculture was plotted. These compositions were plotted separately by each urban main land use types which are commercial, industry and residential (Figure 9). The results showed that all ternary contours have same pattern, but different magnitudes. As shown in Figure 9, the magnitude for commercial: forest: agriculture composition for $\mathrm{PM}_{10}$ was found to be greater than other compositions. This figure supported and strengthened the results from 
the previous ternary plot (Figure 8). Even though the commercial area had the highest contribution towards air pollutant emissions, industrial activities were not far behind commercial activities. Therefore, authorised parties should focus on controlling transportation in commercial and activities in industrial areas. As shown in Figure 9, the residential compositions presented the smallest influence towards the annual average concentration of those air pollutants. Even though residential compositions had the highest population, transportation activities were not as intense and concentrated as compared to commercial areas. This maybe the reason why the residential proportion had the smallest influence towards air pollutant emissions.

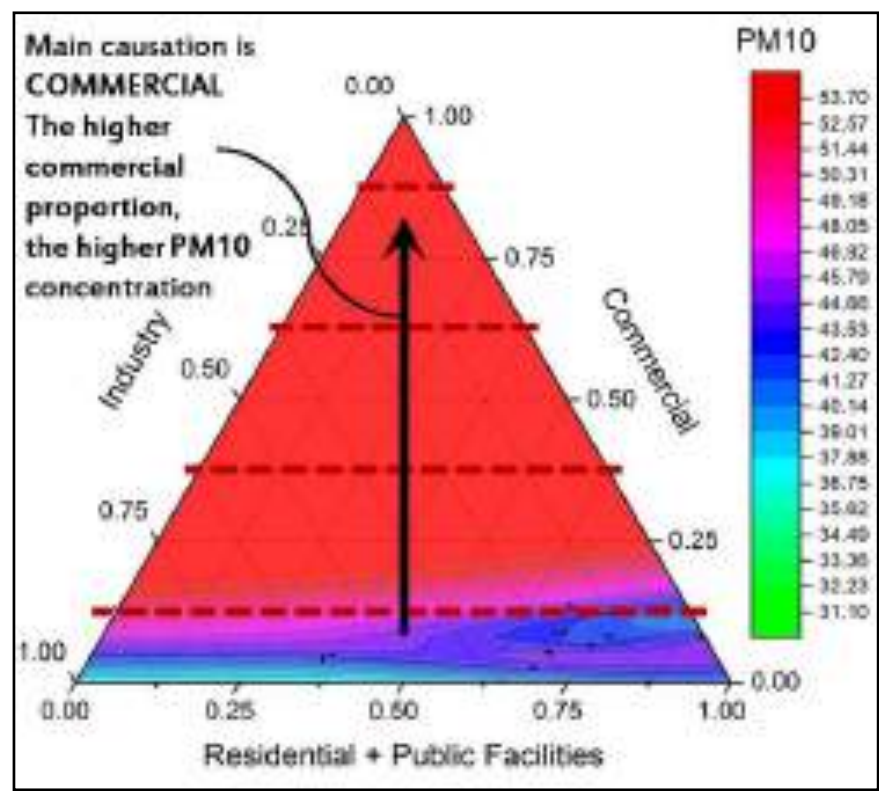

Figure 8: $\mathrm{PM}_{10}$ pattern for industry: commercial: residential land use composition in Iskandar Malaysia

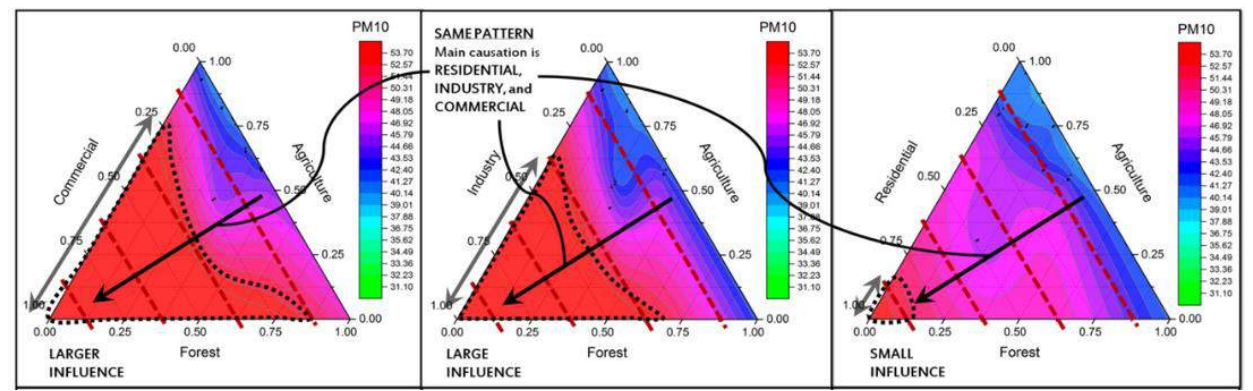

Figure 9: $\mathrm{PM}_{10}$ pattern for urban type: agriculture: forest land use composition in Iskandar Malaysia. 
Muhammad Azahar Zikri Zahari, M. Rafee Majid, Ho Chin Siong, Gakuji Kurata \& Nadhirah Nordin An Investigation on the Relationship between Land Use Composition and PM ${ }_{10}$ Pollution in Iskandar Malaysia

\section{CONCLUSION}

The results shows that air quality as represented by $\mathrm{PM}_{10}$ concentrations were inevitably linked to land use composition at the local level, notwithstanding the more noticeable but intermittent influence of the regional haze episodes. The degree of air pollution was noticeably controlled by the percentage of urban land use when compared to agriculture and forest, with $\mathrm{PM}_{10}$ clearly affected by the size of commercial area, followed by industrial activities. The significant role of the commercial land use, even compared to industrial land use, is due to the pollution coming out from motored vehicles within the area. The use of ternary plots in explaining the relationship between land use composition and air pollution can definitely be extended in practice when deciding the balance between urban land use and other land uses or the balance between different components of urban land uses, i.e. residential, commercial and industrial. In addition to that, this study has also generated important findings on the relationship between land use changes and the local emission scenario in Iskandar Malaysia. Iskandar Malaysia, therefore, needs to be aware of the air pollution at its doorstep, while keeping an eye out for haze from neighbouring countries.

\section{ACKNOWLEDGMENT}

The authors gratefully acknowledge the funding support for this work provided by Ministry of Education, Malaysia and Universiti Teknologi Malaysia (UTM) under Others Grant of Vot number R.J1300000.7301.4B145 and Japan International Cooperation Agency (JICA) under the scheme of SATREPS Program (Science and Technology Research Partnership for Sustainable Development) for the project Development of Low Carbon Scenario for Asian Region.

\section{REFERENCES}

Abas, M. R., Oros, D. R., \& Simoneit, B. R. T. (2004).“Biomass burning as the main source of organic aerosol particulate matter in Malaysia during haze episodes", Chemosphere, 55, 1089-1095.

Department of Environment (DOE), Malaysia (2008). "Malaysia environmental quality report 2008". Kuala Lumpur: Department of Environment, Ministry of Sciences, Technology and the Environment, Malaysia.

Fang, F., Zheng, M., Wang, F., To, K.L., Jaafar, A.B., Tong, S.L., (1999).“The solventextractable organic compounds in the Indonesia biomass burning aerosols - characterization studies", Atmospheric Environment, 33, 783 - 795.

Gramling, C. (2011). "Still in a haze: What we don't know about black carbon", American Geosciences Institute: Earth The Science Behind The Headline.

Graham, B., Mayol-Bracero, O.L., Guyon, P., Roberts, G.C., Decesari., S., Facchini, M.C., Artaxo, P., Maenhaut, W., Koll, P., Andreae, M.O., (2002). "Water-soluble organic compounds in biomass burning aerosols over Amazonia", 1.Characterization by NMR and GC-MS. Journal of Geophysical Research, 107, D20, 8047.

Haq, G. and Schwela, D. (2008). "Urban Air Pollution in Asia”, Foundation Course on Air Quality Management in Asia, Stockholm Environment Institute.

Iskandar Region Development Authority (IRDA), (2006), "South Johor Urbanisation", Comprehensive Development Plan, (10-1)-(10-15). 
Jimenez, J., Wu, C.F., Claiborn, C., Gould, T., Simpson, C.D., Larson, T., Liu, S., (2006)."Agricultural burning smoke in eastern Washington - part I: Atmospheric characterization", Atmospheric Environment, 40, 639 - 650.

Junker, C., Wang, J.L., Lee, C.T., (2009). "Evaluation of the effect of long-range transport of air pollutants on coastal atmospheric monitoring sites in and around Taiwan", Atmospheric Environment, 43, 3374 - 3384.

Kang, C.M., Lee, H.S., Kang, B.W., Lee, S.K., Sunwoo, Y., (2004). "Chemical characterization of acidic gas pollutants and PM2.5 species during hazy episodes in Seoul, South Korea", Atmospheric Environment, 38, 4749 - 4760.

Lin, C.Y., Liu, S.C., Chou, C.C.K., Suang, S.J., Liu, C.M., Kuo, C.H., Young, C.Y., (2005)."Long-range transport of aerosols and their impact on the air quality of Taiwan", Atmospheric Environment, 39, 6066 - 6076.

Ling O. H. L., Ting K. H., Shaharuddin A., Kadaruddin A. and Yaakob M. J. (2010),"Urban Growth and Air Quality in Kuala Lumpur City, Malaysia", The International Journal, Thai Society of Higher Education Institutes on Environment

Liu, T.H., Tsai, F., Hsu, S.C., Hsu, C.W., Shiu, C.J., Chen, W.N., Tu, J.Y., (2009)."Southeastward transport of Asian dust: Source, transport and its contribution to Taiwan", Atmospheric Environment, 43, 458 - 467.

Nguyen, H.T., Kang, C.-H, Ma, C.-J., Choi, K.-C., Kim, J.S., Lee, J.H., Kim, K.H., (2009)."Evidence of long-range transport of pollutants from the size-fractionated ionic composition of aerosols in the Jeju island of Korea", Water, Air, Soil Pollution, 196, 225 - 243.

Nguyen, D. C., (2010). "Influence of Transboundary Pollution of Biomass Burning on Ionic Compounds in Urban Particulates", Department of Environmental Science And Engineering, National University of Singapore.

Niemi, J.V., Saarikoski, S., Aurela, M., Tervahattu, H., Hillamo, R., Westphal, D.L., Aarnio, P., Koskentalo, T., Makkonen, U., Vehkamaki, H., Kulmala, M., (2009). "Long-range transport episodes of fine particles in southern Finland during 1999 - 2007", Atmospheric Environment, 43, 1255 - 1264.

Palatino, M. (2013)."Southeast Asia: The Great Haze of 2013", Global Voices, Southeast Asia.

Radojevic, M. and Hassan, H., (1999).“Air quality in Brunei Darussalam during the 1998 haze episode", Atmospheric Environment, 33, 3651 - 3658.

Ramanathan, V. and Carmichael G. (2008). "What Is Black Carbon", Center for Climate and Energy Solution, Nature Geoscience, 1:221-227.

Sansuddin, N., Ramli, N. A., Yahaya, A. S., MD Yusof, N. F. F., Ghazali, N. A., Al Madhoun, W. A., (2010). "Statistical analysis of $\mathrm{PM}_{10}$ concentrations at different locations in Malaysia", Springer Science+Business Media B.V.

See, S.W., Balasubramanian, R., Wang, W., (2006). "A research of the physical, chemical, and optical properties of ambient aerosol particles in Southeast Asia during hazy and nonhazy days", Journal of Geophysical Research, 111, D10S018, doi:10.1029/2005JD006180.

Soleiman, A., Othman, M., Samah, A. A., Sulaiman, N. M., and Radojevic, M. (2003)."The occurrence of haze in Malaysia-A case study in an urban industrial area", Pure and Applied Geophysics, 160, 221-238. 
Muhammad Azahar Zikri Zahari, M. Rafee Majid, Ho Chin Siong, Gakuji Kurata \& Nadhirah Nordin

An Investigation on the Relationship between Land Use Composition and PM $M_{10}$ Pollution in Iskandar Malaysia

Wang, H., Kawamura, K., Ho, K.F., Lee, S.C., (2006).“Low molecular weight dicarboxylic acids, ketoacids, and dicarbonyls in the fine particles from roadway tunnel: Possible secondary production from the precursors", Environmental Science and Technology, 2006, 40, 6255-6260.

Wang, K., Zhang, Y., Jang, C., Phillips, S., and Wang, B., (2008). "Modeling intercontinental air pollution transport over the trans-Pacific region in 2001 using the Community Multiscale Air Quality modeling system", Journal of Geophysical Research, VOL. 114, D04307, doi:10.1029/2008JD010807.

Ward, T.J., Hamilton Jr, R.F., Dixon, R.W., Paulsen, M., Simpson, C.D., (2006) "Characterization and evaluation of smoke tracers in PM: Results from the 2003 Montana wildfire season", Atmospheric Environment, 40, 7005 - 7017.

Witham, C. and Manning, A., (2007). "Impacts of Russian biomass burning on UK air quality", Atmospheric Environment, 41, 8075 - 8090.

Zhang, R., Han, Z., Cheng, T., Tao, J., (2009)."CChemical properties and origin of dust aerosols in Beijing during springtime",Particuology, 7, 61 - 67 . 